\title{
Competency Profile of Electrical Engineering Graduates Relevant to the Industry
}

\author{
Desy Ayu Permatasari1 and Djemari Mrdapi2 \\ Yogyakarta State University, Yoyakarta, Indonesia \\ Dezi.ayu@gmail.com
}

\begin{abstract}
This research aims to know and to explore the competency profile of Electrical Engineering associate degree graduates of Yogyakarta State University that is relevant to the electrical installation maintenance and reparation industry. This research uses qualitative and quantitative approaches. The data in this research are collected through questionnaire and interview. The research subjects are head of study program, students and supervisors of beverage and clothing industries in Yogyakarta. The analysis technique used in this research is quantitative statistic descriptive technique. The results of this research are: the graduation competency consists of 3 main components which are: knowledge, skills, and soft skills. The findings reveal the competencies which are considered necessary by industries in Yogyakarta. The findings are used as guidelines for electrical engineering graduates in order to fulfill the industrial competency.
\end{abstract}

Keywords: Competence; Electrical Engineering Diploma; Repair And Maintanance ; Industry

\section{$1 \quad$ Introduction}

The 21 st century is marked as a century of openness or globalization which means that human lives in 21 st century experience changes in every business and work result of human [1]. The 21st century expects quality human resources. Quality resources can be realized through vocational education. Vocational education is expected to produce graduates who have knowledge and skills that are relevant to the industrial needs [2]. The graduates are expected to have knowledge not only in certain fields but also wider range of skills [3]. In preparing the graduates to be successful in finding jobs according to their fields, the graduates have to be equipped with relevant competencies in order to fulfill the industrial needs. Kompas in 2008 mentions that "almost $30 \%$ of job vacancies available are not filled because of the applicants do not meet the criteria required by the employer". It means that there are job vacancies available but the competencies or skills and expertise of the applicants do not meet the criteria required by the industry.

In order to achieve the competencies expected by the industrial world, a comprehensive mapping is crucial to be conducted [4]. This mapping can be done to produce matching competency between industry and educational world in which involved the related institution [5]. The next step is to make the curriculum relevant in order to align the world of work and education. University results which at first are minimum knowledge mastery, skills and attitudes that are in accordance with the curriculum target of a study program are substituted with the competencies needed in order for someone to be capable of doing a set of clever actions and fully responsible as the requirements to be considered capable by society to do tasks in certain fields [6].

A research that can be done is to align the education with working world through curriculum that is relevant with the needs of working world. The alignment is an effort to align education as the supplier of resource with the working world as the absorber of human resource that changes dynamically [7]. Before discussing about competencies, making the curriculum relevant is started by analyzing the curriculum documents, industrial standard competency in National Worker Competence Standard of Indonesia (SKKNI), and the National Competence Framework of Indonesia (KKNI) that consist of attitudes, knowledge, and skills competencies needed to be owned by graduates.

The purpose of this research is to see the competence of electrical engineering associate degree and to make it relevant with the electrical installation maintenance and work reparation competency. This research is conducted in Electrical Engineering Associate Degree Program of Yogyakarta State University. Making the curriculum relevant is important in 
arranging graduates' competence. Based on the explanation, the researchers are interested to conduct a research in order to know whether the curriculum is in accordance with the industrial needs or not.

\section{Related Works/Literature Review (13 Points, bold)}

The research is started by defining basic and special skills compiled with data about the basic competence and special skills according to the university. After the competencies have been clearly defined, the basic competencies and special skills according to the industry can be compiled. Definition of competencies according to researchers describes that competencies consist of knowledge, skills, and attitude dimensions. Competencies are acquired through skills practice or field practice and learning process. Competencies show an individual that has acquired knowledge, skills, and attitude needed to do certain tasks in a job [8]. Basic competencies are the core skills needed in daily occupation [9]. Basic competencies are related to knowledge and skills without limiting the content of skills [10]. Basic competencies emphasize on job internalization, learning or self-development. In this research, the term of special skills in industry is used to show professional skills. Professional competencies are related to certain jobs or skills related to the skills' competencies including knowledge, skills and professional attitude [11]. Professional competence is an important factor needed when someone is finishing a job [12]. Peak and Brown define that professional competencies as knowledge, skills, and attitudes that lead to the success of a certain relevant task and job [13]. In short, the researchers have divided the basic and professional competencies.

Graduates competencies from universities in Indonesia are realized in KKNI or National Qualifications Framework of Indonesia which has 4 main parameters conceptually, they are general knowledge, specific knowledge, basic knowledge and attitudes realized through learning achievement which consist of 9 levels, it is realized in level 5 for associate degree [14].

Electrical installers in this research are as designing, building, assembling, servicing, maintaining, checking and testing. Picture is a technique realized in previously-agreed symbols. Picture can be in form of sketch, perspective, projection, and layout. Analysis is a set of calculation derived from technical comparison. Kinds of analysis can be formed in electrical power, environment/physical building, installation components, and description as an additional analysis that covers the explanation about the way of equipment/material installation. System control planning of building is full of skills in electrical, heater, ventilation, air conditioner, and communication technology [15]. Electrical installation design consists of picture of situation where design is going to be installed and connected to the electrical source. Layout design shows the exact electricity equipment and control services, such as point of lights, socket, switch, electrical motor, PHB, and others

\section{$3 \quad$ Material \& Methodology}

This research uses qualitative method. The researchers use qualitative research to know the curriculum developed and its relevance towards the industrial competence. This research is conducted in February to April 2018 in Electrical Engineering Associate Degree Program of Yogyakarta State University. Subjects in this research are Head of study program, students, and supervisors in electrical industry installation. The data collection techniques used are questionnaire and interview. The instrument validity uses content validation. The researchers use an analysis technique model that consists of four components, namely data condensation, data display, drawing, and verifying conclusions [16].

\section{$4 \quad$ Results and Discussion}

This research illustrates competencies which consist of knowledge, attitude, and competence in electrical maintenance and reparation for electrical engineering associate degree. These competencies are really needed in electrical maintenance and reparation industry.

\subsection{Knowledge}

Analysis of curriculum and National Worker Competency Standard of Indonesia reveal the list of knowledge considered necessary by industry. Based on the list, knowledge can be divided into "Electrical Circuits", "Analog Electronics", "Installation and Electrical Machines", "Power Electronics", "Computer Network", "Industrial Electronics", and "Maintenance and Reparation technique".

Table 1. Necessary knowledge of electrical engineering associate degree graduates.

\begin{tabular}{ll}
\hline Knowledge & $\%$ \\
\hline Installation and electrical machine & 31.3 \\
\hline Maintenance and reparation technique & 12,5 \\
\hline Power electronics & 9.4 \\
\hline Industrial electronics & 6.3 \\
\hline Electrical circuits & 6.3 \\
\hline Computer network & 6.3 \\
\hline
\end{tabular}




\begin{tabular}{ll}
\hline Analog electronics & 3.1 \\
\hline PLC & 3.1 \\
\hline
\end{tabular}

As shown in table 1, knowledge about installation and electrical machine is almost 1/3 (31.3\%) of the needs, making it the most important knowledge needed by industry, because there are a lot machines used in production process of an industry. This finding identifies the needs of electrical engineering graduates who have knowledge in installation and electrical machines before entering working world.

\subsection{Skills}

Based on the analysis of National Worker Competency Standard of Indonesia and industry, skills in maintaining and repairing electrical installation are needed to be owned by electrical engineering associate degree graduates. In general,

skills can be classified into category of hard skill and soft skill. Hard skill is a technical skill needed by someone who is relevant with the task on working area, while soft skill is someone skills in communicating with others. Soft skill competencies consist of listening, speaking, giving feedback, participate in discussion and capable of solving problems. Soft skill ability is something that is hard to count or measure even though it is observed.

Tabel 2. Hard skills ability that are necessary to be owned by graduates

\begin{tabular}{ll}
\hline Skills & $\%$ \\
\hline Doing basic electrical equipment reparation and electrical motor works & 50.0 \\
\hline Doing basic work of repairing supporting equipment & 3.1 \\
\hline $\begin{array}{l}\text { Asembling and disasembling electrical component and electronic in industria } \\
\text { equipment }\end{array}$ & 43.8 \\
\hline Maintaining electrical panels and low voltage power switch equipment & 43.8 \\
\hline Maintaining and repairing low voltage equipment and its circuit & 34.4 \\
\hline Maintaining and repairing fire protection equipment and its circuit & 15.6 \\
\hline Maintaining and repairing security system equipment and its circuit & 6.3 \\
\hline Maintaining and repairing electrical equipment on electrical machines & 6.3 \\
\hline Maintaining and repairing electrical connection equipment and its circuit & 43.8 \\
\hline $\begin{array}{l}\text { Disconnecting and connecting electrical equipment connected from explosion } \\
\text { with low voltage system. }\end{array}$ & 75.0 \\
\hline
\end{tabular}

\subsection{Soft Skills}

Table 3 shows the results of soft skills category. As it is known that communication skills are needed the most (28.1\%) in industry. Findings show that industry emphasizes their requirement for good communication skills in soft skills competency is needed for employee. Other skills are presentation skill $(25 \%)$ and interpersonal skill $(18.8 \%)$. Other than that, the user in this case is the industry also states the leadership and time management skills (9.4\%) as needed in job.

. Table 3. Important soft skills for electrical engineering associate degree graduates

\begin{tabular}{|l|l|}
\hline Soft skills & $\%$ \\
\hline Communication & 28.1 \\
\hline Presentation & 25.0 \\
\hline Interpersonal & 18.8 \\
\hline Leadership & 9.4 \\
\hline Time management & 9.4 \\
\hline
\end{tabular}

Clearly, the findings about soft skills show that the ability to communicate effectively is very needed by industry. Demand on interpersonal skills indicates that industry has high expectation towards the skills of graduates in order to work well with others and in team. Presentation skill is needed when the electrical engineering students are requested to give presentation to other employees periodically.

Time management and leadership skills are also expected to be owned by graduates to make sure the tasks are finished on time.

Generally, soft skills needed that have been identified in this research are enough to illustrate the tasks of maintenance and reparation supervisors which probably include to report about the production machines performance continuously.

Graduates are required to communicate, interact, present, lead, and manage time well. Soft skills of electrical engineering associate degree graduates are very important because it can influence them in planning and arranging work and delegating the task directly according to needs.

The requirement expected are not just hard skills but also soft skills that can determine the success or failure of the graduates in entering working world. 


\subsection{Personal skills}

Table 4 shows frequency distribution graphic from research related to personal attributes. The result of research reveals that "capable of working independently/with minimum supervision" $(40.6 \%)$ as the most wanted attribute, followed by "working in team" (15.6\%) and "capable of working under pressure" (9.4\%). Demands on graduates with these characteristics show that industry puts the ability of electrical engineering associate degree graduates to be able to work under pressure either independently or in team. Characteristics also mentioned include "flexible and open attitude", "willing to learn", "creative", and "proactive". Even though these characteristics only consist of $3.1 \%$ of the ads. Findings reveal that industry also looks for individual that is motivated, mature and responsible and have positive attitude.

Table 4. Important personal skills ability to be owned by electrical engineering associate degree graduates.

\begin{tabular}{l|l} 
Personal skills & $\%$ \\
\hline capable of working independently & 40.6 \\
\hline Team player & 15.6 \\
\hline capable of working under pressure & 9.4 \\
\hline Flexible and open attitude & 6.3 \\
\hline Willing to learn & 6.3 \\
\hline Creative & 6.3 \\
\hline Proactive & 3.1
\end{tabular}

\section{Conclusion}

In complete, the result of this research gives illustration about main competencies needed by graduates who work in maintaining and repairing electrical installation. The profile developed is based on curriculum and National Worker Qualification Standard of Indonesia. The data about the importance of competence can be developed from more industries or stakeholders to validate the instrument to strengthen the findings in this research. Other than that, research about competence gap also has to evaluate how far curriculum of a university can adapt with industry. Based on series of results acquired, it is enough to complete graduates' competencies and it also can be used as competency framework form graduates competence of maintaining and repairing for electrical engineering. Therefore:

(1) Graduates have to own the skills competencies in order to fulfill the competencies needed by industry,

(2) Graduates have to own attitudes and knowledge in order to improve basic skills in working,

(3) Graduates have to be able to communicate effectively with every aspect of the company,

(4) Graduates has to be able to fulfill the general, special, knowledge, and attitude competencies.

\section{Acknowledgement}

This research is fully supported by reseach and evaliation education and thanks to Prof Djemari Mardapi who has accompanied to write this research. This is reasonable to be published.

\section{References}

[1]. A. Dyankov, Current issues and trends in technical and vocational education. Proc. $21^{\text {st }}$ UNESCO Conf. on Technical and Vocational Education.Paris, France, 1996, 40 -50.

[2]. GKGSingh, and SKG Singh, Malaysian graduates' employability skills.Unitar e-Journal.4 (1), 2008, 14-44

[3]. HASpille, Postsecondary curricula must emphasize generic employability skills, Adult Learning, 5 ( 5), 2004,17 19.

[4]. AP Carnevale, LJGainer, you. S.Meltzer, Workplace basics: the skills employers need (Washington DC, Erics, 2009)

[5]. W. Grubb, Betwixt and between: education, skills, and employment in Sub-Baccalaureate labor markets. (Berkeley, CA: ERIC, ED 353412 2009).

[6]. CM, Ile, MWAsoegwu, and GCChukwugbo, Essentials of vocational education and technical education forbeginners. (Awka: Marpat Educational Research and Publishers, 2005 ).

[7]. FJ, Krieg, P.Brown, andJ.Ballard, Transition: school to work. (Bethesda, MD: thenational Association of School Psychologists, 2005).

[8]. L.Koffel, Teaching workplace skills: creative ways to teach students the skills employers want. (Houston, TX: Gulf, 2004).

[9]. CGNwokomah, Strategy for Attaining functional vocational and technical education in the 21 st century in Nigeria. 
Journal of Education in Developing Areas. 1 (14), 2005, 53-61.

[10]. I. Sule, How relevant are our Nigerian schools? In JA Akintola (Ed.), Issues and problems of technical education at the secondary school level in Nigeria.1 (Zaria, Nigeria, the National Education Research Council, 2009) 55-60.

[11]. PCOkwelle, Development and validation of an instrument for assessing practical skills in building electrical system in Nigeria. Nigeria Technical Trends in Engineering and Applied Sciences.3 (3) .2011, 25-31

[12]. Hall, GE and Jones, HJ, Competency-Based Education: Process for Improvement of Education. Englewood Cliffs, NJ: Prentice-Hall (1976).

[13]. Stasz, C., Assessing Skills for Work: TwoPerspectives.Oxford: Oxford Economic Papers (2000).

[14]. Kemendikbud. (2013). Kerangka Kualifikasi Nasional Indonesia (KKNI). http://sindiker.dikti.go.id/dok/permendikbud/Permendikbud73-2013Juklak KKNI.pdf.

[15]. OHIdriss, and EY Garba, technical and entrepreneurial education.for Vocational schools and businessmen. (Lagos: T. Richard, 2007).

[16]. GD Cheek, the secondary vocational programs, in AJ Pautler, (Ed.), Vocational education in the 1990's: major issues, 2 (AnnArbor, MI: Prakken, 1993), 45-70 